\title{
PENENTUAN LOKASI DISTRIBUTOR DENGAN MENGGUNAKAN ANALYTICAL HIERARCHY PROCESS DAN SKALA LIBERATORE
}

\author{
DYAH KUSMINDARTI \\ Plan International Indonesia \\ Jalan Ketintang Madya 76 Surabaya \\ E-mail: a_shafa@hotmail.com
}

\begin{abstract}
Based on the natural problems of company, researcher try to give alternative trouble-shooting of decision making by using Method of Analytical Hierarchy Process (AHP) and supported with Method 5 Scale of Liberatore. After doing assessment to criterion sub and criterion with method of AHP later in continuing with assessment 5 Scale of Liberatore from each criterion sub with giving one of scale size measure which consist of outstanding $(O)$, good $(G)$, average $(A)$, fair $(F)$ and poor $(P)$ in each criterion sub to know biggest global weight among some alternative location to be selected. And chosen distributor location I region of Jakarta because having biggest global weight that is 0.401 with criterion weight of marketing factor equal to 0.481, Expense of equal to 0.114 and Continuity of Product equal to 405, while Region of Semarang (alternative to II) and Magelang (Alternative to III) weight of global successively equal to 0.354 and 0.245.
\end{abstract}

Key words: location, distributor, analytical hierarchy process, scale of liberatore

\section{PENDAHULUAN}

Pemenuhan kebutuhan konsumen adalah segala-galanya baik dari produk itu sendiri ataupun dari segi pelayanan yang meliputi ketepatan waktu, ketersediaan produk dan lain sebagainya.

Berdasarkan masalah di atas salah satu solusi yang dapat dijadikan adalah dengan mendirikan sebuah lokasi sebagai penyaluran (distributor/ warehouse). Karena sejauh ini Perusahaan baru mempunyai 2 (dua) penyalur (distributor) saja yaitu di Malang dan Surabaya. Oleh karena itu, sudah semestinya perusahaan mencoba untuk membuat alternatif-alternatif lokasi lain sebagai lokasi distributor. Salah satu metode dalam pengambilan keputusan pemilihan Lokasi Distributor yang digunakan dalam penelitian ini adalah metode Analytic Hierarchy Process (AHP) dengan didukung 5 skala liberatore. Metode Analytic Hierarchy Process (AHP) ini berfungsi sebagai metode pendekatan untuk sebuah keputusan dalam suatu susunan multicriteria yang cukup kompleks. Yang nantinya didukung oleh 5 skala liberatore, untuk membantu memudahkan dan mengurangi jumlah dari penilaian berpasangan yang dibutuhkan antara subfaktor dan pilihan alternatif yang memunculkan banyak subfaktor.
Tujuan penelitian ini adalah menentukan lokasi distributor dari beberapa lokasi alternatif yang diinginkan perusahaan.

\section{METODE}

Data-data yang diperlukan dalam penelitian ini meliputi: data perusahaan secara umum, data sumber daya manausia SDM (pimpinan dan karyawan), data lokasi (yang dipertimbangkan oleh perusahaan), data kriteria utama dan subkriteria dalam pemilihan lokasi. Metode yang digunakan dalam penelitian ini mengaplikasika AHP, adapun langkah-langkah yang dilakukan sebagai berikut:

Selain kuesioner kriteria dan subkriteria peneliti juga menyusun kuesioner perbandingan berpasangan untuk penilaian lokasi distributor. Pengisian untuk kuesioner penilaian lokasi distributor dilakukan dengan cara yang sama dalam pengisian kuesioner pembobotan kriteria dan subkriteria.

Menyusun struktur hierarki. Setelah dilakukan wawancara kepada para pipimpinan dan karyawan perusahaan untuk mengetahui kriteria dan subkriteria pemilihan lokasi distributor yang digunakan untuk mengevaluasi tentang lokasi 
yang akan dinilai, selanjutnya disusun struktur hierarki.

Penilaian perbandingan berpasangan. Pada tahap dilakukan penentuan tingkat kepentingan dari elemen-elemen tiap level kriteria dan subkriteria. Penilaian perbandingan ini diisi oleh para pakar (dalam hal ini dilakukan oleh bagian marketing dan penjualan) yang mengetahui tentang kriteria lokasi distributor yang diinginkan perusahaan.

Uji konsistensi. Di dalam penentuan bobot masing-masing kriteria perlu dilakukan pengujian terhadap konsistensi preferensi untuk mengetahui apakah ada unsur acak.

Langkah-langkah pengujian konsistensi data adalah sebagai berikut. (1) Mengalikan setiap elemen pada setiap kolom matriks penilaian perbandingan berpasangan dengan bobot yang berkaitan. Hasil perkalian matriks baru. (2) Menjumlahkan masing-masing elemen pada setiap matriks baru. Hasil penjumlahan ini akan membentuk vektor jumlah baris. (3) Membagi vektor jumlah baris dengan vektor bobot. Hasil pembagian ini akan membentuk vektor baru. (4) Menghitung rasio konsistensi dimana dalam penelitian ini peneliti menggunakan sumber buku dari Saaty (2000) karena dinilai lebih baru. (5) Penilaian dikatakan konsistensi apabila rasio konsistensi $\leq 0,10$ maka ada unsur acak di dalam memberikan penilaian.

Penentuan bobot kriteria dan rangking dengan 5 Skala Liberatore. Berdasarkan hasil perhitungan perbandingan berpasangan yang diperoleh pada tahap sebelumnya dilakukan perhitungan bobot untuk kriteria dan subkriteria. Setelah diperoleh bobot dari masing-masing kriteria, kemudian setiap kriteria dimasukkan ke dalam 5 skala liberatore, yaitu terdiri atas Outstanding (O), Good (G), Average (A), Fair (F), dan Poor (P), dengan disesuaikan dengan penilaian antaralternatif (Tam, 1993).

\section{HASIL DAN PEMBAHASAN}

Peneliti menganalisis hierarki model rating yang terdiri atas analisis setiap tingkatan hierarki, yaitu Tujuan, Kriteria utama (tingkat II), subkriteria (tingkat III), subkriteria (Tingkat IV) dan Alternatif (Tingkat V) pada Gambar 1.

Hierarki ini merupakan hierarki fungsional karena disusun menjadi bagian-bagian menurut hubungan yang penting. Tingkatan yang paling atas atau tingkat I (satu) merupakan tujuan keseluruhan yang ingin dicapai. Tujuan (goal) ini adalah Pemilihan lokasi distributor sesuai perumusan masalah. Sedangkan tingkat II merupakan kriteria utama, yaitu elemen pendukung pertama yang berkaitan dari pemilihan lokasi distributor. Tingkat III dan IV merupakan sub- subkriteria, yaitu elemen pendukung dari kriteria utama, dari Tingkatan III dan IV ada Tingkat V di mana tingkatan ini merupakan subkriteria pendukung dan disebut dengan 5(lima) skala Liboratore, yaitu beberapa kriteria yang terdiri atas Outstanding (O), Good (G), Average (A), Fair (F), dan Poor (P) untuk mengetahui suatu tingkatan ranking dari setiap subkriteria di atasnya. Kemudian tingkatan paling bawah adalah alternatif, yaitu usulan-usulan yang akan ditentukan untuk lokasi distributor mana yang nantinya akan terpilih. Dalam penelitian ini terdapat satu goal, yaitu pemilihan lokasi distributor yang dikehendaki, dengan alternatif usulan yang ditawarkan adalah 3 lokasi distributor.

Dalam hierarki fungsional, level di bawah level tujuan adalah level Kriteria Utama (Tingkat II) yang harus dipenuhi untuk mencapai tujuan. Karena tujuan hierarki adalah Pemilihan Lokasi Distributor untuk perusahaan maka level di bawah tujuan itu kriteria utama yang harus dipenuhi untuk melakukan pemilihan Lokasi Distributor. Kriteria terpilih berdasarkan hasil wawancara dengan responden adalah biaya, kelangsungan produk, dan pemasaran.

Perusahaan mengharapkan alternatif yang dipilih dapat menentukan sebuah lokasi distributor yang dapat mempermudah perusahaan dalam melakukan kegiatan pengiriman dan penyaluran produk. Analisis subkriteria dalam kriteria biaya. Terdapat 2 subkriteria dalam kriteria biaya. Perusahaan berpendapat bahwa dalam penentuan lokasi distributor yang berhubungan dengan biaya adalah biaya langsung dan biaya tidak langsung. Adapun untuk kriteria kelangsungan produk, kriteria ini meliputi sebuah ketahanan produk ketika sampai kepada konsumen. Berdasarkan wawancara dengan responden subkriteria yang muncul adalah sebagai berikut. Analisis subkriteria dalam kriteria kelangsungan produk. Terdapat 2 subkriteria dalam kriteria kelangsungan produk. 
Karakteristik pekerja untuk mengidentifikasi karakter sosial secara umum dan khususnya secara individu budaya yang ada pada masyarakat di lokasi tersebut. Subkriteria kedua, yaitu kedekatan pabrik, perusahaan menginginkan lokasi untuk distributor sedekat dan strategis mungkin. Selanjutnya adalah kriteria pemasaran subkriteria yang muncul adalah sebagai berikut.

Analisis subkriteria dalam kriteria pemasaran. Terdapat 2 subkriteria dalam kriteria pemasaran. Perusahaan menginginkan dengan adanya lokasi distributor yang memiliki kinerja tepat waktu dalam pengiriman karena jika terjadi keterlambatan akan menghambat proses produksi selanjutnya dalam hal keberadaan pasar sangat diperhitungkan untuk hal pemasaran. Lingkungan makro juga menjadi pertimbangan yang tidak dapat diabaikan karena kestabilan suatu wilayah sangat memengaruhi kesatbilan permintaan pasar.

Setelah memunculkan subkriteria untuk tingkatan III, tingkatan di bawahnya berdasarkan hasil wawancara dengan responden subkriteria tingkat IV pada perusahaan dalam pemilihan lokasi distributor untuk subkriteria biaya langsung adalah sebagai berikut.

Analisis subkriteria IV dalam subkriteria biaya langsung. Terdapat 2 subkreteria dalam subkreteria biaya langsung, perusahaan berpendapat bahwa dalam penentuan lokasi distributor yang berhubungan dengan biaya langsung adalah pertama rasio upah, untuk melihat kemampuan perusahaan dalam mengeluarkan gaji untuk karyawan dan yang kedua biaya transportasi, biaya yang dikeluarkan oleh perusahaan untuk sebuah produk ketika sampai kepada konsumen. Adapun untuk subkriteria biaya tidak langsung, subkriteria ini berhubungan denga biaya yang akan dikeluarkan perusahaan dengan jangka waktu yang relatif lebih panjang daripada dengan insensitas biaya langsung. Berdasarkan wawancara dengan responden subkriteria dalam biaya tidak langsung yang muncul adalah sebagai berikut.

Analisis subkriteria IV dalam subkriteria biaya tidak langsung. Terdapat 3 subkriteria dalam kriteria biaya tidak langsung. Subkriteria di atas merupakan biaya-biaya yang akan dikeluarkan oleh perusahaan akan tetapi tidak berhubungan langsung dengan operasional produk. Selanjutnya adalah subkriteria karakteristik pekerja, subkriteria IV yang muncul adalah sebagai berikut.

Analisis subkriteria IV dalam subkriteria karakteristik pekerja: kualitas tenaga kerja, ketersediaan tenaga kerja. Terdapat 2 subkriteria dalam subkriteria karakteristik pekerja. Perusahaan menginginkan lokasi distributor yang dipilih memiliki tipe pekerja dengan kinerja yang diinginkan oleh perusahaan dengan ketersediaan

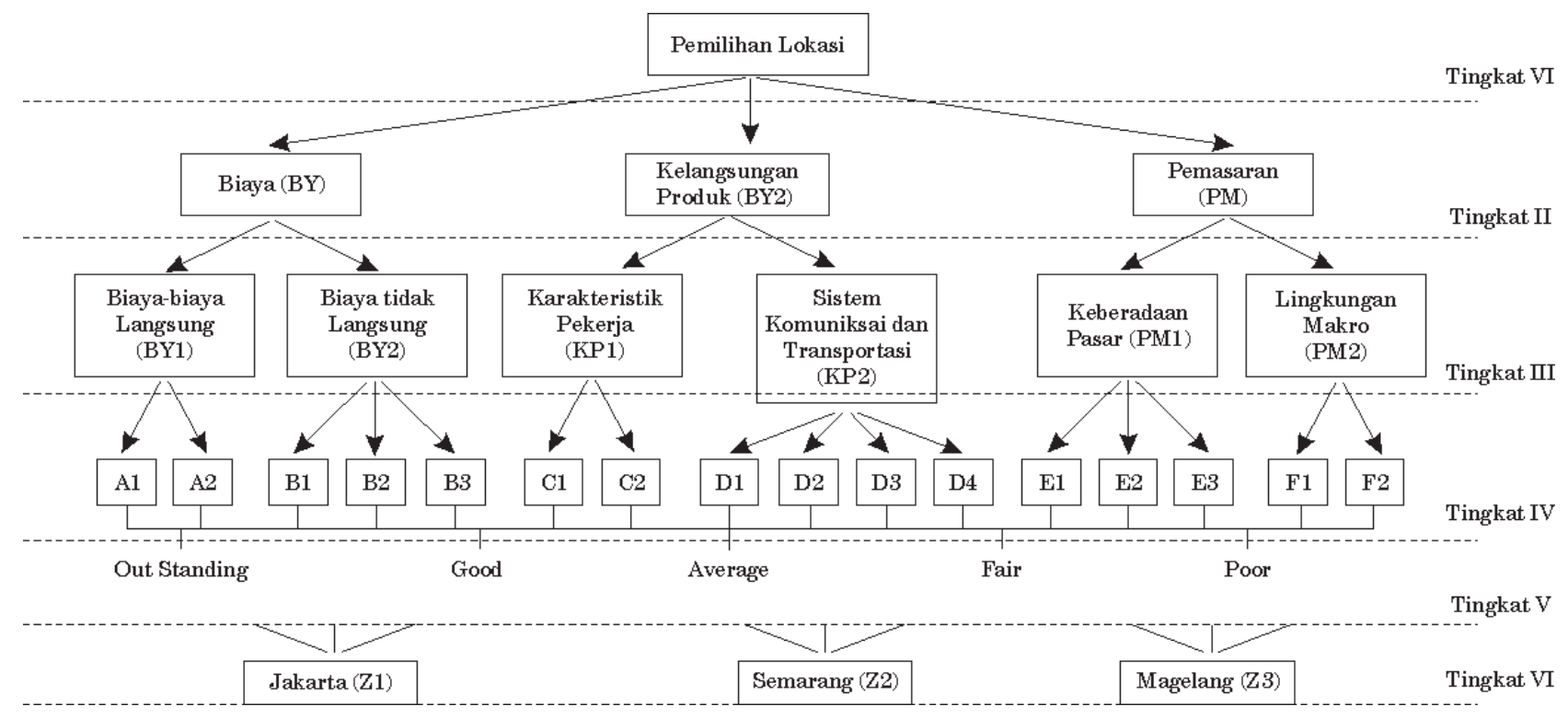

Gambar 1. Struktur kriteria utama dan subkriteria pemilihan lokasi distributor 
yang memadai khususnya dari segi SDM (Sumber Daya Manusia). Berikutnya adalah subkriteria kedekatan dengan Pabrik berdasarkan wawancara, maka muncul subkriteria IV, adalah sebagai berikut.

Analisis subkriteria IV dalam subkriteria system informasi dan transportasi: eksistensi mode transportasi, sistem telekomunikasi, kualitas dan keandalan mode transportasi, kecepatan dan respons. Terdapat 4 subkriteria dalam subkriteria kedekatan pabrik. Dalam subkriteria hal yang dipertimbangkan yang pertama eksistensi mode transportasi ini berhubungan dengan jalur yang akan ditempuh dalam hal pengiriman, apakah jalur darat, laut, udara dan sebagainya. Yang kedua sistem telekomunikasi berhubungan dengan system yang ada pada wilayah tersebut apakah sudah memadai atau belum. Yang ketiga kualitas dan keandalan mode transportasi hal ini berhubungan dengan kendaraan yang akan digunakan apakah jalur yang digunakan dimiliki oleh perusahaan atau belum, dan sudah layakkah? Dan keempat kecepatan dan respons, berhubungan dengan subriteria di atas untuk megidentifikasi dengan adaya beberapa kriteria di atas sudah mendukung untuk hubungan antara produk dengan pangsa pasar dalam hal penyaluran.

Adapun untuk subkriteria keberadaan pasar, di mana subkriteria ini berhubungan dengan pangsa pasar yang ada pada setiap lokasi alternatif yang akan dipilih. Analisis subkriteria IV dalam subkriteria keberadaan pasar: ukuran pasar, insenitas permintaan, respon pasar. Adapun selanjutnya adalah subkriteria dalam kriteria lingkungan makro. subkriteria ini mempunyai 2 kategori, di antaranya adalah: Analisis subkriteria IV dalam subkriteria lingkungan makro: catatan stabilitas daerah, peraturan lingkungan.

Terdapat 2 subkriteria dalam subkriteria lingkungan makro. Perusahaan menginginkan lokasi distributor yang dipilih memiliki lokasi yang stabil baik dari segi kehidupan sosial ataupun kebijakan peraturan daerah yang diharapkan dapat menunjang utuk perbaikan kelangsungan perusahaan.

Alternatif yang digunakan sesuai tujuan penelitian pemilihan lokasi distributor di mana perusahaan memilih sebuah lokasi berdasarkan pertimbangan-pertimbangan yang kemudian dimunculkan melalui beberapa kriteria dan subkriteria untuk dijadikan dasar pertimbangan dalam pemilihan lokasi dengan dihitung secara matriks antar kriteria dan subkriteria dengan beberapa lokasi alternatif. Adapun lokasi-lokasi alternatif untuk pemilihan lokasi distributor adalah Jakarta, Semarang, Magelang. Analisis pembobotan kriteria ditunjukkan pada Gambar 2 adalah prioritas kriteria dari yang terbesar ke yang terkecil dengan menggunakan bantuan software Expert Choice. Dapat dilihat bahwa Pemasaran merupakan Kriteria dengan prioritas tertinggi dengan bobot 0.481. Berdasarkan wawancara dengan responden bahwa kriteria pemasaran lebih penting karena akan mempengaruhi kelangsungan sebuah perusahaan karena tujuan awal dengan didirikannya lokasi distributor adalah untuk penyebaran produk seluas-luasnya.

Kriteria kelangsungan produk mempunyai bobot 0,405 dan kriteria biaya dengan bobot 0,114 merupakan kriteria dengan prioritas tertinggi kedua dan ketiga. Nilai rasio inkonsistensinya adalah 0,03 lebih kecil daripada 0,1 sehingga pembobotan kriteria konsisten.

Analisis pembobotan subkriteria dalam kriteria biaya. Gambar 3 adalah prioritas subkriteria dalam Kriteria biaya dari yang terbesar ke yang terkecil:

Dapat dilihat bahwa subkriteria biaya langsung mempunyai bobot yang lebih besar, yaitu 0,750 dan biaya tidak langsung mempumyai prioritas yang lebih kecil, yaitu 0,250. Hal ini karena perusahaan sangat mementingkan biaya yang langsung berhubungan dengan produk. Nilai rasio Inkonsistensinya adalah 0,00 lebih kecil daripada 0,1 sehingga pembobotan subkriteria dalam kualitas konsisten. Analisis pembobotan subkriteria dalam kriteria kelangsungan produk. Gambar 4 adalah prioritas subkriteria dalam kriteria biaya dari yang terbesar ke yang terkecil. Dapat dilihat bahwa subkriteria kelangsungan produk bahwa karakteristik pekerja memiliki bobot 0.250 sedangkan sistem telekomunikasi dan transportasi memiliki bobot 0,750. Ini berarti perusahan lebih mementingkan sistem telekomunikasi dan transportasi dibanding karakteristik pekerja. Nilai 
rasio Inkonsistensinya adalah 0,00 lebih kecil daripada 0,1 sehingga pembobotan subkriteria dalam biaya konsisten.

Analisis pembobotan subkriteria dalam kriteria pemasaran. Gambar 5 adalah prioritas subkriteria dalam kriteria pemasaran dari yang terbesar ke yang terkecil. Dapat dilihat bahwa subkriteria keberadaan pasar memiliki 0,833 dan sedangkan sedangkan lingkungan makro memiliki bobot 0,167 . Ini berarti perusahan lebih mementingkan kriteria keberadaan pasar dibanding lingkungan makro.

Nilai rasio inkonsistensi adalah 0,00 lebih kecil daripada 0,1 sehingga pembobotan subkriteria dalam pengiriman konsisten.

Analisis pembobotan subkriteria dalam subkriteria biaya langsung. Gambar 6 adalah prioritas subkriteria dalam subkriteria biaya langsung dari yang terbesar ke yang terkecil.

Dapat dilihat bahwa subkriteria A1 (rasio upah) mempunyai bobot 0,750 sedangkan A2 (biaya transportasi) mempunyai bobot 0,250 . Ini berarti perusahan lebih mementingkan subkriteria A1 (rasio upah) daripada A2 (biaya transportasi).

Nilai rasio inkonsistensinya adalah 0,00 lebih kecil daripada 0,1 sehingga pembobotan subkriteria dalam biaya langsung konsisten.

Analisis pembobotan subkriteria dalam subkriteria biaya tidak langsung. Gambar 7 adalah prioritas subkriteria dalam subkriteria biaya tidak langsung dari yang terbesar ke yang terkecil.

Dapat dilihat bahwa subkriteria B1 (insentif pajak dan struktur pajak) dan B3 (insenif financial) sama-sama mempunyai bobot 0,40 sedangkan B2 (kewajiban cukai) mempunyai bobot 0,20 . Ini berarti perusahan lebih mementingkan subkriteria B1 dan B3 daripada B2.

Nilai rasio inkonsistensinya adalah 0,00 lebih kecil daripada 0,1 sehingga pembobotan subkriteria dalam biaya tidak langsung konsisten.

Analisis pembobotan subkriteria dalam subkriteria karakteristik pekerja. Gambar 8 adalah prioritas subkriteria dalam subkriteria karakteristik pekerja dari yang terbesar ke yang terkecil.

DapatdilihatbahwasubkriteriaC2 (ketersediaan pekerja) mempunyai bobot 0,750 sedangkan $\mathrm{C} 1$

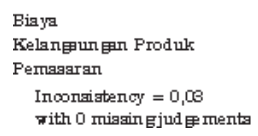

Gambar 2. Prioritas kriteria tingkat II dari yang terbesar ke yang terkecil

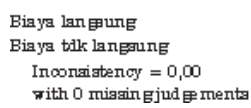

Gambar 3. Prioritas sub kriteria tingkat III dari yang terbesar ke yang terkecil

(perfomasi pekerja) mempunyai bobot 0,250. Ini berarti perusahan lebih mementingkan subkriteria C2 (ketersediaan pekerja)) dari pada C1 (perfomasi pekerja).

Nilai rasio inkonsistensinya adalah 0,00 lebih kecil daripada 0.1 sehingga pembobotan subkriteria dalam Karakteristik Pekerja konsisten. Analisis pembobotan subkriteria dalam subkriteria sistem komunikasi dan transportasi. Gambar 9 adalah prioritas subkriteria dalam subkriteria karakteristik pekerja dari yang terbesar ke yang terkecil. Dapat dilihat bahwa subkriteria D4 (kecepatan dan respons) mempunyai bobot 0,376 mempunyai bobot yang paling besar. D2 (sistem telekomunikasi) dan D3 (kualitas dan keandalan mode transportasi) mempunyai bobot urutan kedua dan ketiga, yaitu 0,346 dan 0,158. Sedangkan bobot terkecil terdapat pada D1 (eksistensi mode transportasi) mempunyai bobot 0,121 . Ini berarti perusahaan lebih mementingkan subkriteria D4 (kecepatan dan respons).

Nilai rasio inkonsistensinya adalah 0,02 lebih kecil daripada 0,1 sehingga pembobotan subkriteria dalam sistem komunikasi dan transportasi konsisten.

Analisis pembobotan subkriteria dalam subkriteria kedekatan pabrik. Gambar 10 adalah prioritas subkriteria dalam subkriteria kedekatan pabrik dari yang terbesar ke yang terkecil.

Dapat dilihat bahwa subkriteria E3 (respons pasar) mempunyai bobot 0,582, E2 (insensitas permintaan) mempunyai bobot 0,309 . sedangkan E1 (ukuran pasar) mempunyai bobot 0,109. Ini berarti perusahan yang paling penting adalah subkriteria E3 (respons pasar). 
Eeberadaen Famr

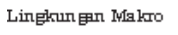

Inoonaistency $=0,00$

Fith 0 migsin Ejuid f menta

Gambar 4. Prioritas sub kriteria tingkat III dari yang terbesar ke yang terkecil

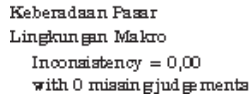

Gambar 5. Prioritas sub kriteria III dari yang terbesar ke yang terkecil

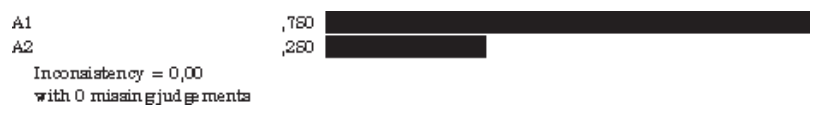

Gambar 6. Prioritas sub kriteria tingkat IV dari yang terbesar ke yang terkecil

Nilai rasio inkonsistensinya adalah 0,00 lebih kecil daripada 0,1 sehingga pembobotan subkriteria dalam kedekatan pabrik konsisten.

Analisis pembobotan subkriteria dalam subkriteria lingkungan makro. Gambar 11 adalah prioritas subkriteria dalam subkriteria lingkungan makro dari yang terbesar ke yang terkecil.

DapatdilihatbahwasubkriteriaF1(ketersediaan pekerja) mempunyai bobot 0,833 sedangkan F2 (perfomasi pekerja) mempunyai bobot 0,167 . Ini berarti perusahan lebih mementingkan subkriteria F1 (ketersediaan pekerja)) daripada F2 (perfomasi pekerja). Nilai rasio inkonsistensinya adalah 0,00 lebih kecil daripada 0,1 sehingga pembobotan subkriteria dalam lingkungan makro konsisten. Analisis penilaian lokasi distributor. Penilaian dilakukan dengan menjumlahkan semua kriteria di atas dari tingkatan II, III dan IV, sehingga didapatkan bobot Global dari setiap subkriteria Tingkat IV, kemudian dibandingkan dengan menggunakan Skala Liberatore menggunakan penilaian lima skala, yaitu Outstanding (O), Good (G), Average (A), Fair (F), dan Poor (P). Kelima skala ini akan dibandingkan satu sama lain kemudian dicari bobot lokalnya. PJCM dari kelima skala tersebut mengikuti skala 1-9 yang dikembangkan oleh Saaty, TL (1980) berdasarkan penelitian Liberatore sehingga setiap subkriteria mempunyai masing-masing tingkatan skala terhadap perbandingan pemilihan alternatifalternatif lokasi distributor yang ada.

Hasil perhitungan menunjukkan bahwa nilai bobot relatif untuk model Liberatore adalah Outstanding: 0,513; Good: 0,261; Average: 0,129; Fair: 0,063; Poor: 0,034. Kemudian bobot global dari subkriteria tingkat IV dijumlahkan dengan nilai skala pada setiap alternatif lokasi distributor. Hasil yang didapatkan sebagai berikut lihat Tabel 1.

Tabel 1. Bobot global untuk 3 lokasi distributor

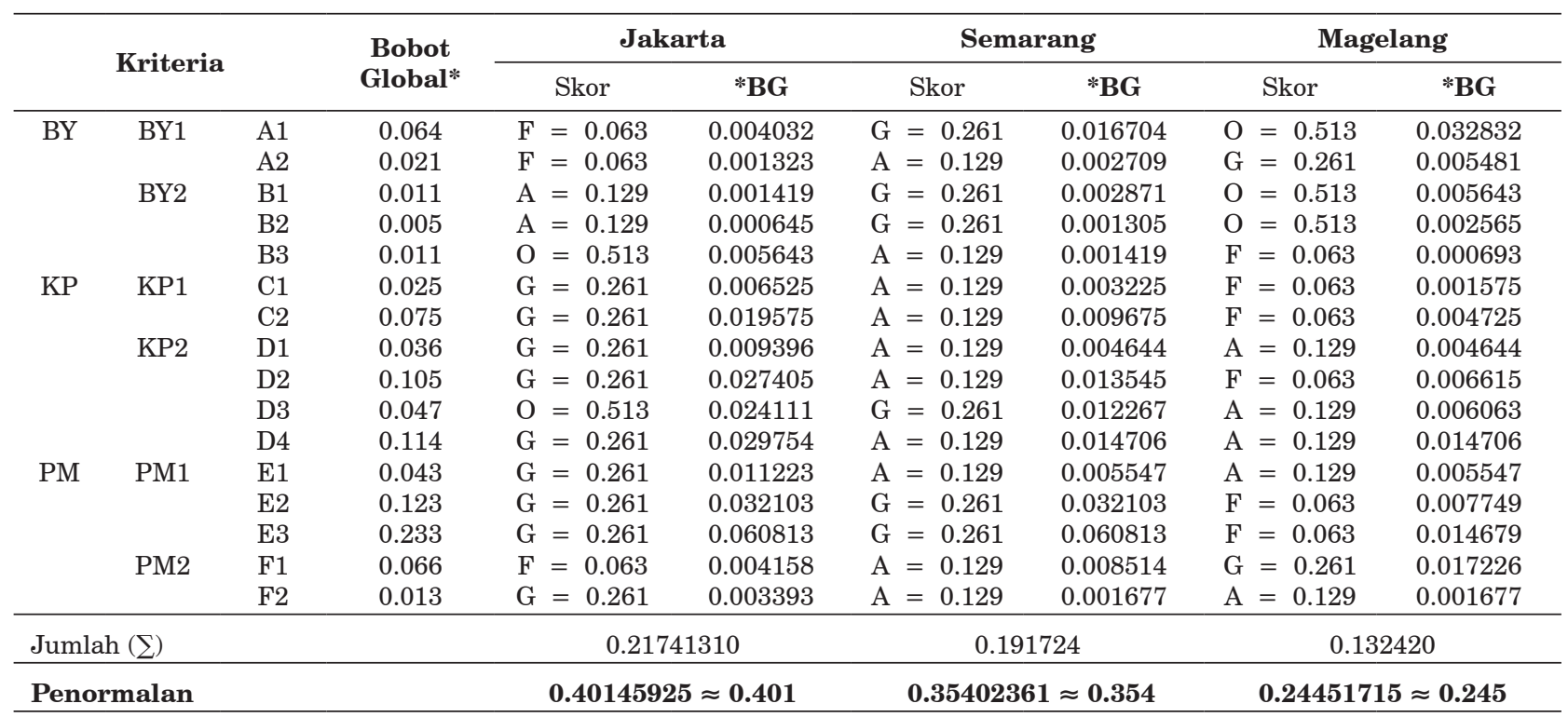




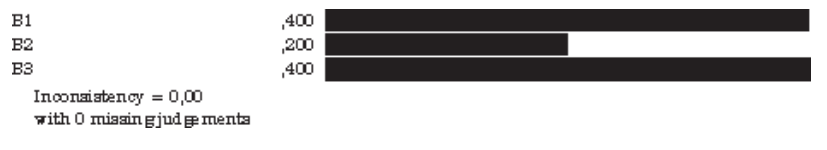

Gambar 7. Prioritas sub kriteria tingkat IV dari yang terbesar ke yang terkecil

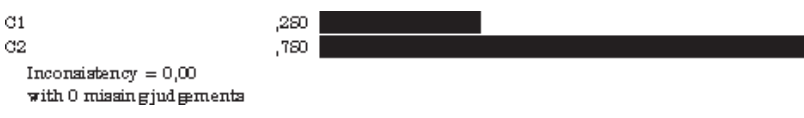

Gambar 8. Prioritas sub kriteria tingkat IV dari yang terbesar ke yang terkecil

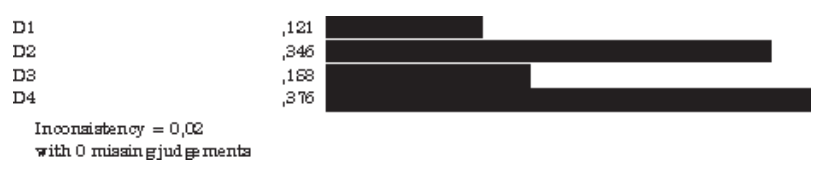

Gambar 9. Prioritas sub kriteria tingkat IV dari yang terbesar ke yang terkecil

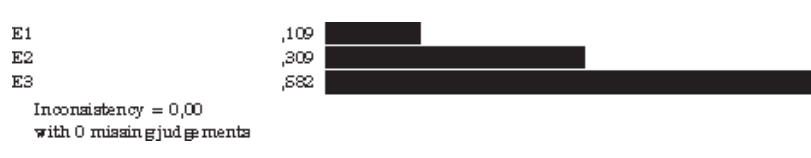

Gambar 10. Prioritas sub kriteria tingkat IV dari yang terbesar ke yang terkecil

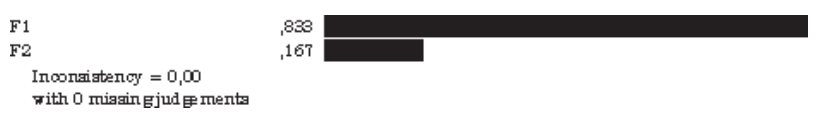

Gambar 11. Prioritas sub kriteria tingkat IV dari yang terbesar ke yang terkecil

Berdasarkan hasil perhitungan tersebut maka dapat diurutkan berdasarkan bobot global lokasi distributor, sebagaimana dapat disimak pada Tabel 2.

Tabel 2. Urutan Bobot Global Lokasi Distributor

\begin{tabular}{lc}
\hline \multicolumn{1}{c}{ Lokasi Distributor } & Bobot Global \\
\hline Jakarta (Z1) & 0.401 \\
Semarang (Z2) & 0.354 \\
Magelang (Z3) & 0.245 \\
\hline
\end{tabular}

Berdasarkan Tabel 3 dapat diketahui bobot akhir untuk Z1, Z2 dan Z3 adalah 0,401, 0,354 dan 0,245 sehingga Wilayah Jakarta (Z1) dapat dikatakan terpilih sebagai lokasi distributor karena mempunyai bobot global yang paling besar.

Setelah terpilih Jakarta maka langkah yang akan diambil perusahaan terus mengoptimalkan pemasaran yang ada ini terlihat pada data sebelumnya jakarta mempunyai prospek yang cukup baik dari tingkat penjualan.

Tabel 3. Data Bulan Maret s/d Juli 2007

\begin{tabular}{lccccc}
\hline \multirow{2}{*}{ Wilayah } & \multicolumn{5}{c}{ Permintaan (per/unit) } \\
\cline { 2 - 6 } & Maret & April & Mei & Juni & Juli \\
\hline Jakarta & 1745 & 1698 & 1734 & 1750 & 1770 \\
\hline
\end{tabular}

\section{SIMPULAN}

Berdasarkan penelitian yang telah dilakukan maka dapat diambil suatu kesimpulan bahwa.

Dalam penilaian evaluasi pemilihan Lokasi Distributor diantara wilayah Semarang, Magelang dan Jakarta menurut PT Tlogomas Engineering Plastik Industri Malang (TEPIN) wilayah yang terpilih untuk alternatif I (pertama) adalah wilayah Jakarta, sedangkan wilayah Semarang dan Magelang berturut-turut adalah alternatif ke II (dua) dan III (ketiga).

\section{DAFTAR PUSTAKA}

Chopra, S., dan Meindl, P., 2001. Supply Chain Management: Strategy, Planning, and Operation. New Jersey: Prentice Hall.

Mulyono, Sri, 1996. Teori Pengambilan Keputusan. Jakarta: Lembaga Penerbit Fakultas Ekonomi UI.

Pujawan, Nyoman, 2005. Supply Chain Management, Edisi Pertama. Surabaya: Guna Widya.

Saaty, T.L., 1993. Proses Hierarki Analitik untuk Pengambilan Keputusan dalam Situasi yang Kompleks. PT. Pustaka Binamon Pressindo.

Syamsi, I., 2000. Pengambilan Keputusan Dan Sistem Informasi, Jakarta: PT Bumi Aksara.

Tam, CY., 1993. An application of the analytic hierarchy process in vendor selection of a telecommunications system. MSc Engineering Management dissertation, Department of Manufacturing Engineering and Engineering Management, City University of Hong Kong, Kowloon, Hong Kong. 